\title{
The urgency of religious and cultural science in STEM education: A meta data analysis
}

\author{
Woro Sumarni, Zulfatul Faizah, Bambang Subali, W. Wiyanto, Ellianawati \\ Science Education Study Program, Universitas Negeri Semarang, Indonesia
}

\begin{abstract}
Article Info
Article history:

Received Jan 2, 2020

Revised Aug 12, 2020

Accepted Oct 11, 2020

\section{Keywords:}

Ethnoscience

Religion

RE-STEM

STEM education

ABSTRACT

The 21st century education engages students to have higher order thinking and scientific literacy skills. However, these abilities in Indonsia are still relatively low, especially student's scientific literacy skills. One solution to the problem of low scientific literacy skills in Indonesia is the application of STEM education. However, as technology advances pursued in STEM education, religious and cultural sciences increasingly separate themselves from science. Cultural science is rarely implemented in learning so that many students do not know their own culture. The contra between science and religion also makes students's perception of religion and science are two independent knowledge and cannot be united. Through literature studies that have been carried out from various journal article search sites, this article discusses how important religious and cultural sciences are to be implemented into STEM education. The relationship between religion and science, culture and science, culture and religion and the urgency of religion and culture in STEM education are also discussed in this article. The results of this study propose solutions so that science education can be implemented with RE-STEM learning to overcome the gap between religion, culture and science. So, that students will have a more balanced knowledge in religion, ethnoscience and science from RE-STEM integration.
\end{abstract}

This is an open access article under the CC BY-SA license.

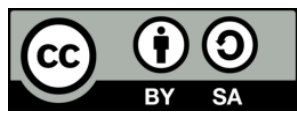

\section{Corresponding Author:}

Woro Sumarni,

Science Education Study Program, Postgraduate,

Universitas Negeri Semarang,

Postgraduate Campus, III Kelud Utara Road, Semarang 50237, Indonesia.

Email: worosumarni@mail.unnes.ac.id

\section{INTRODUCTION}

Each individual is required to have 21 st century skills namely problem solving, communication, collaboration, teamwork, critical thinking, creative thinking and the use of information technology and communication $[1,2]$. These skills are critical and creative thinking skills which the part of the higher level thinking skills that are being developed in the Indonesian education curriculum. This skill has begun to be supplied by teachers even though there are still many obstacles in its implementation in the classroom.

Likewise, with science literacy were also some significant skill in the 21 st century is the result of learning desired by educators [3, 4]. But unfortunately, the level of scientific literacy of students in Indonesia is still relatively low. This can be seen in the scientific literacy ranking of 15-year-old Indonesian students based on PISA respectively 383, 382, 403, for 2009, 2012 and 2015. The acquisition of low scientific literacy scores shows that the science knowledge of Indonesian students is still not extensive. Discussion of moral value is not far from culture and religion. Indonesia is a country that holds tight culture and manners, and also uses strong guidelines from religious knowledge. Technological advances that are growing rapidly even 
more pushing back the old culture. Cultural knowledge is becoming increasingly distant from the world of education. The dominance of knowledge and norms of science in the STEM curriculum is based on Western knowledge which makes people become alien to their own culture [5]. Therefore, the development of scientific literacy needs to be focused on curriculum content that pays attention to culture and daily life to make it more contextual [6].

One solution of this problem is to make culture as a source of learning science for student through ethnoscience. Ethnoscience learning helps unite local science with formal science with a more balanced process [5]. Ethnoscience based learning is also capable of eliciting scientific attitudes [7] and student activeness during learning activities [8]. The implementation of ethnoscience makes it easier for students to learn science by linking science from the culture around their homes. Some research also shows that ethnosciences can indeed increase students' scientific literacy [9, 10]. Learning science is expected to be an appreciation of nature which is the most important component for scientific literacy [11]. The progress of science also shows that general science increasingly away from natural laws that have been written in every religious guideline belief adhered to by society. Whereas the factors of success in teaching in the 21 st century era, one of them is applying moral values in it [12]. Science literacy can't be separated from morals and ethics, especially in the attitude of science. Not only to understand the methods of science but also how to be good in every methods accomplishment. The best moral cultivation is through attitudes that are regulated by one's religion. However, people's understanding of science, for example, empirical analysis tends to analyze religion only as a potential driver of the rejection of science [13] so that religion in science is increasingly isolated [14]. This problem can be overcome by using the suggestion proposed by Jones so that in this study applied science learning is based on religious views about science [14].

Religion and culture with STEM are two aspects that appear far apart [14]. These problems led to improvement of the quality of education solutions with how to integrate cultural and religious sciences to the natural sciences that students learn [15]. The role of religious science in shaping morals and ethics is part of streghtening science in forming STEM identities $[16,17]$. However, educators often feel confused about the scope of what must be known in implementing religious and cultural knowledge in learning. So, further knowledge is needed about the research that has been carried out by researchers in implementing religious knowledge into STEM or cultural sciences into STEM, or both simultaneously. This article aims to describe novel technical result of conceptual and empirical literature review related to the implementation of religious and cultural sciences into STEM in education. The formulations of the problem from this discussion are: 1) How important is religious knowledge in learning science? 2) How to integrate cultural and religious science in learning science? 3) What is the relationship between religion and culture and STEM?

This study is synthesize literature study to answers these questions: How important is religious knowledge and cultural science in learning science and the relationship between religion, culture and STEM education. Collectively this question tries to describe novel technical result of the interrelationship between religious and cultural sciences in the implementation of STEM education and recommend new research to integrate it in the class. The first and second questions identify the urgency of religious and cultural sciences in the current development of science and how to implement it. The third question identifies the relationship between religious and cultural sciences and STEM education.

\section{RESEARCH METHOD}

The method for synthesizing this literature follows several steps to ensure the validity of the results. Some questions that arise are explained in detail to help understand the results that can be presented.

\subsection{Article identification}

This literary research identifies a number of articles that have been published in several journals that describe the urgency of religious and cultural sciences in science learning and their relevance to STEM education. Journal articles are selected through the initial search stage using ERIC and Tandfonline. The search terms used are religious, religion, STEM and culture, but the search results are too broad so that keywords are more specific to the words religious science, science and religion, culture and religion in education, ethnoscience, scientific literacy, and limited STEM education from 2016 to 2019. Hundreds to thousands of articles were obtained, but articles were sorted based on the interrelationships between the three keywords; 1) religious knowledge, 2) ethnics, and 3) STEM. Articles seen by reading the abstract relation shown and taken articles who fit the criteria of the first 100 articles first in order of relevance. The selected article must meet the criteria of 1) the focus of discussing the relevance or urgency of religious knowledge in science education, 2) the urgency of ethnoscience in increasing scientific literacy, 3) the relationship of ethnoscience with STEM, and 4) the relationship of religious science with STEM education. Filtering articles 
according to the criteria obtained 75 relevant articles from more than 20,000 related articles in the period of 2016 to 2019.

\subsection{Analysis procedure}

Analysis of the article is arranged in three stages; 1) stages I and II, namely a subset of articles to develop category schemes and article keyword criteria to take important variations in article search, 2) stage III, namely applying the category and criteria scheme on the specified article search site, and 3) stage III including checking the selected journal articles in the top 100 of the order of relevance in each search word used and retrieval according to established criteria. Collectively this question tries to describe novel technical result of the interrelationship between religious and cultural sciences in the implementation of STEM education today. The first and second questions identify the urgency of religious and cultural sciences in the current development of science. The third question identifies the relationship between religious and cultural sciences and STEM education.

\section{RESULTS AND DISCUSSION}

\subsection{Ethnoscience and its relationship with religious sciences}

Moral and ethics can't be denied the importance in the world of science. Both are important aspects for the success of teaching in this century [12]. Moral and ethics itself cannot be separated from the guidance of religion. Ethics is one of importance factors of the relationship between religion and science [18], while both are believed to affect the state of education in some countries [19]. Religion is the core of the historical knowledge of science that contrasts sharply with social life [20]. Religious science is an important factor that influences the perception and understanding of science and information science [21]. The results of research in the United States show that only a few scientists perceive that religion and science are contradictory, even religious individuals tend to have high levels of fish education [22]. However, people's understanding of science, for example, empirical analysis tends to analyze religion only as a potential driver of science enforcement [23] and tends to avoid linking the contents of their religious books with science [10, 24].

The relationship between religion and science is explained by three possibilities [25]. First, religion and science are independent aspects, with each of them having its own explanation of the world. Second, the possibility that religion and science can actually complement each other, just as religion can answer questions that science cannot. Third, the possibility that science and religious knowledge are indeed conflicting. The relationship of religion with science into four, where the fourth relationship is conditionally independent (science and religion can stand alone without being related, but on the other hand both have a relationship) [26]. However, about $50 \%$ of scientists in both biology and physics support that science and religion are independent. Some scientists from several countries consider that religion and science are in conflict.

This conflict between religion and science occurs where religion and science compete in providing moral guidance and explaining world history. If we look at the principle of these two aspects, it can be seen that the conflict between science and religion occurs with a conflict between the two where religion is a law that uses the principle of belief. Religious science is absolute while science operates on the principle of unbelief. Another contradiction is where many religious scientists, but there are still many scientists in the world who conduct research by integrating religion feel discriminated against by most scientists who are not religious [27]. Religious individuals have higher education, but religious scientists rarely carry out their religious obligations and tend not to rely on their holy books and worship into their knowledge [22, 28]. Young people who believed in science in ways that did not meet the requirements did not believe in religion more [29]. Students in religious schools have a different view of science than students in national schools [30].

The weakness of the implementation of this religious-science relationship is that some scientists still consider religion to be only a human relationship with their God, so religion cannot be widely viewed scientifically as the creation of the universe is written in the Qur'an or the Bible. Teaching and learning activities also still rarely link between religion and science [31], so students' perceptions of the two are also still very narrow [32]. This problem still raises the gap between religion and science [33]. Therefore it is important for teachers to facilitate space for prospective scientists to get to know how religion relates to science and its limits [14, 34, 35].

In addition to religious conflicts with science, in reality the two have a close relationship as they should [36]. Both seem loose, but science cannot forever be separated from religious knowledge, such as the pros and cons of biotechnology or the use of stem cell therapy that is rife today that is still hung by religion [37, 38]. The interesting relationship about how Islam views the science as so amazing [39]. Knowledge can also be implemented into learning to glorify the greatness of God in creating the universe. 
Contemporary Islamic scientists have linked the religious knowledge they have in each of their discoveries and research [21]. One of contemporary scientist caled Gulen provides a harmonious relationship between religion and science [39]. The history of science is explained that comes from Islamic science and other beliefs of his era.

In fact, when religious knowledge is tried to be applied to natural science learning in schools, students find memorable lessons, are challenged to think differently, and appreciate that science can have religious perceptions. Students with science-religion who have the most positive perspective on Darwinian evolution [40]. Students' opinions about science-religion and found that students were interested in exploring both, but did not have the intellectual tools to do [41]. Learning that relates religion to science must be involved in every moral, affective and spiritual dimension of students to reject the conflict between science and religion [42]. Scientists must appreciate the value of religious cognitive science [43]. Limiting learning about religion and science, let alone separating between the two basically releases human intelligence from the three dimensions. Learning that delivers the relationship between science and religious knowledge supports students' high-level thinking skills [44]. Individuals who can link scientific knowledge with religious knowledge are individuals who have high literacy abilities [45].

Contemporary scientists have also exemplified how science is explained by the scriptures owned by religious people [21, 39]. The relationship between religion and science can be realized in school education by applying science from a religious perspective, or vice versa. Currently, students in religious schools have low knowledge of science and students in secular schools have low religious knowledge [29]. There are still many concerns in many countries that students do not have a good understanding of the scope of science and religion or how the two are related [46]. However, students in religious schools feel more challenged when discussing science because it is considered counter to their religion [29]. Students in secular schools are also more challenged when discussing religion because they are considered to be against their knowledge and do not believe in religion. This situation provides an opportunity for teachers to make a link between the two by taking advantage of student interest in both faith-based and public schools. Learning that applies religious science helps students to develop an understanding and appreciation of the relationship between religion and science [46]. Religion teachers with teachers of general subjects such as mathematics, science, and social affairs can work together to insert faith in each subject [25].

The insertion of religious knowledge into science subjects seems to be the right middle way. Although science without religious knowledge does not seem problematic, scientific thinking that is far from religious science will cripple scientific knowledge. Science teachers need to be encouraged to broaden the science-religion perspective in order to explain the right science-religion topic [42]. Do not let the teacher give a wrong understanding that causes misconceptions in students. The question of the nature of knowledge needs to be presented if students can develop a better understanding of religious knowledge and students understand how to present their understanding [46]. Teachers must first understand the history of science and religion to be able to teach the philosophy of science and religion and their attachments [42]. In a school environment where there are religious minority students, teachers need to conduct tolerant and friendly learning for all students with various cultures and religions [47]. Teachers should have the skills tools used to manage classrooms in conditions of cultural and religious diversity in order to convey the relationship between science and religion properly [47].

\subsection{Ethnoscience and its relationship with religious sciences}

Ethnoscience is scientific knowledge from the perspective of indegenous knowledge in a particular language and culture [5, 48, 49]. Ethnoscience translates knowledge of the community's knowledge gained from experience and beliefs that have scientific facts [50]. The efforts to create an integrated learning environment with the local culture, compile things that function as knowledge for others, how to protect themselves and the botanical knowledge of previous communities as part of science learning is called the ethnographic approach $[43,51]$. Ethnoscience learning is very important to find out phenomena that are considered and organize student learning processes [3] and bring students' initial knowledge to the real concept. The Indonesian nation will not lose its identity if the teacher can integrate ethnoscience in the form of a unique culture in his area into learning, it help teacher to improve students' scientific thinking skills [3]. Integration of ethnoscience into learning also increases student cultural awareness, and students' scientific literacy skills [10, 52]. Ethnoscience integrated science module also effective in science learning in order to improve student achievement [53]. The application of ethnoscience is believed to be effective learning for science class $[2,9,54]$. Therefore, teachers need to be equipped with original knowledge in their respective regions with the support of institutions and governments so that students get a relationship of cultural knowledge with scientific knowledge [55].

Science and culture have a close relationship, so does culture and religion [56]. Religion is considered a cultural system [57]. Religion in some environments is seen as an integral part of culture, both 
of which are closely related [37]. The religious norms prevailing in society usually become a repetitive habit, so that religious and cultural knowledge are integrated in their social life. The purpose of religious and cultural education is to foster indigenous knowledge by bringing the values of traditional beliefs and religions [58].

The examples of incorporation application of religious and etnoscience is using local cultural theme for teaching that can be explained the concept of science. One of them is the making of Canna Noodle, which is a typical food of Majasari Village, Bukateja District, Purbalingga Regency. Minyong is a noodle made from traditional canna starch. Minyong has long been produced for generations, but its production has continued to decline. Canna is a local tuber that is increasingly rare because of its use is less than optimal. Canna has higher fiber and mineral content than other tubers. Nutritional composition of macronutrein canna starch consists of amylose, amylopectin, crude fat, high crude fiber, crude protein, starch, ash, and water. Components of canna starch micronutrients include high calcium, phosphorus and vitamin C. Canna starch has about 3\% fiber which is commonly used as processed transparent noodles [54]. The Majasari village community also produces canna starch into transparent noodles called Minyong. The process of making Minyong involves heating the canna starch porridge using fire so that it can be studied the process of transferring heat energy from the fire to the canna pulp mixture through conduction and convection. The next process is the printing of noodles by being rolled onto a banana leaf and then dried by the sun. This process shows the utilization of heat radiation that can be learned by students.

The role of the teacher is very important in the preservation of these special foods, where the role of the teacher as a facilitator of cultural preservation to the next generation. The teacher must recognize and preserve culture in life through learning. Another culture that can be taken as a source of student learning is a water barrel or a water jug which has the property of being able to lower temperature of the water and keep the temperature of the water still fresh. The process of making dung dung ice can also be used as a student prerequisite activity. Minyong is noodle that made from canna starch. Canna that from Indonesia is a species of Canna discolor Lindl or Canna edulis from the family Cannaceae. Canna is a plant that grows in the tropics of Asia which is starting to exist a little because few people consume it [47]. Canna has beautiful flowers and disease resistance. Canna plants supplement their food reserves in the rhizoma. Canna or Canna indica $L$. has the classification as in Table 1.

\begin{tabular}{cc} 
Table 1. Classification of canna plants \\
\hline Kingdom & Plantae \\
\hline Sub Kingdom & Viridiplantae \\
Infra Kingdom & Sterotophyta \\
Super Divisi & Embryophyta \\
Divisi & Tracheophyta \\
Sub Divisi & Spermatophyta \\
Kelas & Magnoliopsida \\
Super Ordo & Lilianae \\
Ordo & Zingiberales \\
Famili & Cannaceae \\
Genus & Canna L \\
Spesies & Canna indica L. \\
\hline
\end{tabular}

Canna bulbs are harvested and made canna starch as a basic ingredient of Canna Noodle. The process of making canna starch is by grating the canna that has been cleaned and peeled, then squeezed using water to then filtered between the essence of the starch with the cane pulp. Canna starch is allowed to stand until it gets sediment starch then dried using solar thermal energy. This process can be taken as a study of ethnics in integrated science learning in class 7 in heat material. Canna starch that is ready for use is made canna porridge with vegetable oil and salt. Canna porridge produced is still processed in the traditional way using a furnace. After the canna pulp thickens, it is digitized and ready to be printed using banana leaves. All the dough has been completely printed and dried immediately in the hot sun. The drying process takes approximately 7-8 hours in sunny weather conditions. The process of making canna noodles can be studied the concepts of science and implementation of religiosity as in Table 2.

Implementation of religious-ethnoscience as a source of learning science by using this theme is enough to be used as a topic in several science learning material. There are still many other cultures that can be taken as a source of learning such as the use of water barrels, angklung musical instruments and also brick making. The development of ethnographic learning like this must have a link between curriculum systematic, informal, and general knowledge from the community about natural phenomena or culture that exists [59]. 
Table 2. The concept of science based on religious-ethnoscience

\begin{tabular}{l}
\hline \multicolumn{1}{c}{ Indicators } \\
\hline Understanding the \\
procedure of classifying \\
biotic and abiotic as part \\
of scientific work, and \\
classifying various \\
biotic and abiotic things \\
based on observed \\
characteristics
\end{tabular}
characteristics of substances, as well as physical and chemical changes in substances that can be used for daily life (for example mixed mixture)

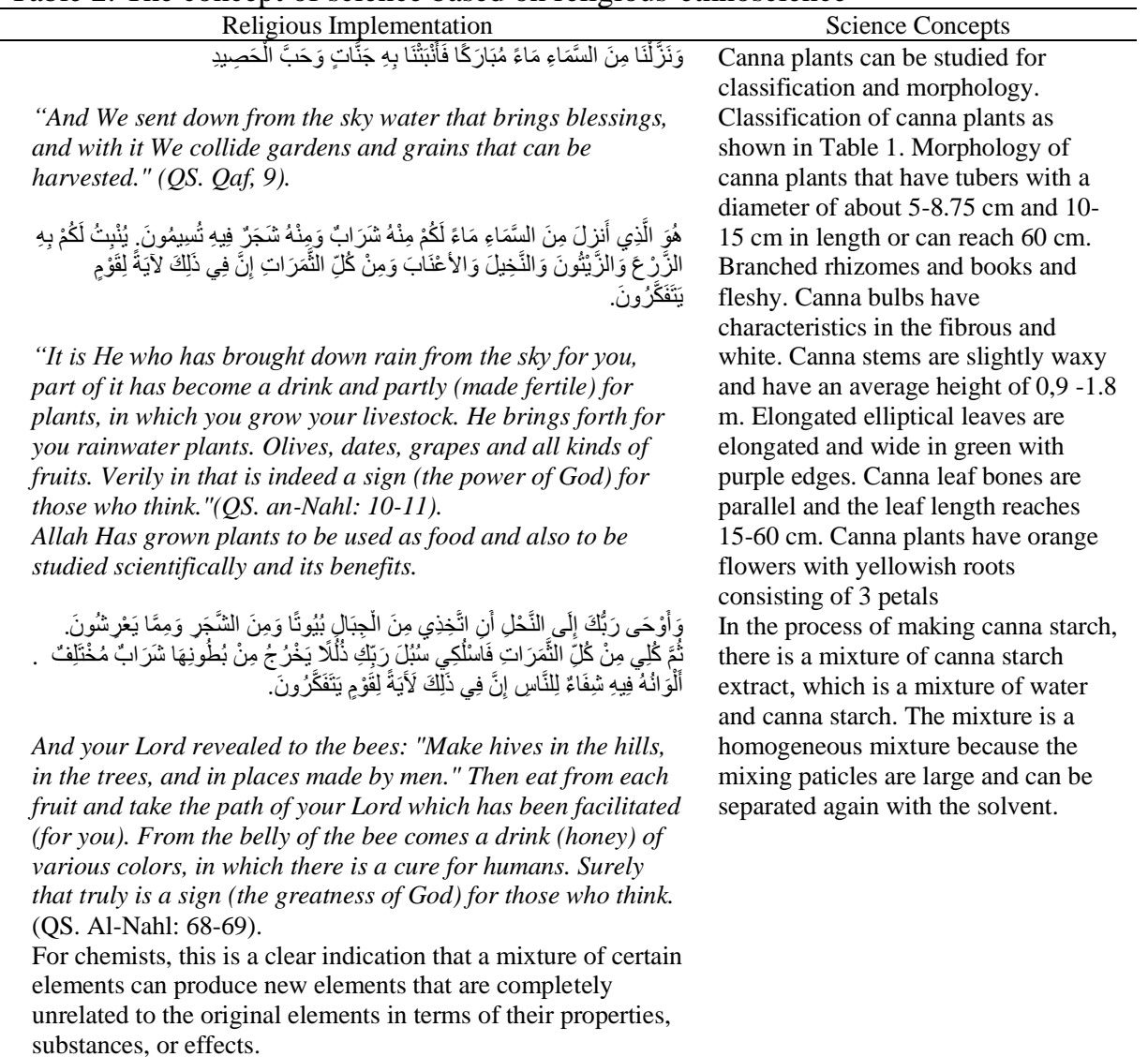

\subsection{Religious and ethnoscience with science, technology, ethnoscience and mathematics (RE- STEM)}

Science, technology, engineering and mathematics are the four disciplines of science are commonly called STEM. The first use of this term is often credited to Judith Ramalay at the US National Science Foundation (NSF) in 2001 who reused the term, then used by NSF as SMET [57]. However, the early history of SMET or STEM has not yet received a clarity of its origin. STEM education in several countries has been included in the special majors of concern at this time, even the graduates are reproduced. Secondary education in Indonesia is starting to take part in the developing STM education. STEM education has an important contribution to school institutions [60]. Global demands bring education curricula to improve the application of STEM-based learning as 21st century skills [27, 61]. The success of the STEM curriculum is influenced by the teacher's interest in the STEM education itself [62]. Many teachers agree on STEM but do not have to believe it's self to implement it [63]. Teachers are still experiencing confusion to implement STEM, while there are still many people have begun to implement STEM not correctly understanding how STEM itself [64]. Teachers and administrators also suggested that the preparation of the integration of STEM will require rethinking and redesign the curricula [63].

Student interest in STEM is influenced by several things, including the closeness and trust of parents with children [36, 65], gender, career [66], student motivation and confidence [67, 68]. STEM education is believed to be able to improve students' scientific understanding [40]. STEM based learning shows a higher score in problem solving [69], but its success requires a link between science and real world problems $[23,59]$. Learning without the real world, learning in isolation and apart like most existing learning makes students not interested in science and mathematics [27].

Special learning designs in integrated STEM learning can lead students to be more motivated in linking science concepts with the real world [70]. Through STEM integration, the learning environment of students becomes better so that it can help teachers improve their conceptions of science and mathematics [71], showing teacher perceptions about STEM, personal knowledge, and understanding of STEM bringing effectiveness in their own classrooms [61]. Integrated STEM education program presents a pedagogical approach based on collaboration, direct, and inquiry [72]. STEM education motivates the learning environment and directs students to play a game that supports student problem solving [73]. STEM 
makes learning more interesting and increases attention and elements of pleasure for students [72]. The creation of a pleasant learning atmosphere supports scientific literacy [74], creativity and problem solving.

There are several cases such as in one of the Catholic schools studied showing a gap between culture, religion and STEM. This case carries the urgency of applying religious and cultural sciences to be applied in science learning, especially STEM education [75]. The application of STEM by using religious and ethnics learning resources is expected to increase knowledge in the context of science that maintains culture and religion. Religious science has an important part in shaping the STEM identity which these two aspects reinforce each other [16]. STEM identity needs to be developed based on the difference between students' religious beliefs and their learning concepts in the classroom [16]. Students who have confidence given learning about the relationship of religion and culture tend to have a higher interest in STEM than nonreligious groups [17]. The incorporation of religion and culture into science learning will be an interesting combination to be applied in the future. It can be a solution to the educators that can overcome the gaps and conflicts between religious knowledge, culture and science by teaching students about the meaning of attachment between these three aspects. Kang \& Peters formed integrated ethnoscience and STEM into ethno-STEM [15]. A solution in line with combining integrated learning is ethno-STEM then we added religious values so that it became integrated learning RE-STEM (Religious-Ethno-STEM).

\section{CONCLUSION}

This study showed that the development of scientific literacy skills in education needs to be based on learning based on religious-ethnographic studies. When students are invited to see the surrounding natural phenomena including local culture, indirectly, students will be invited to think literally about science. Various studies have proven that etnosains based learning can help students to improve students' scientific literacy skills. The urgency of religious and cultural science in education is concern to educators and researchers. The relationship between religion and science may have its own independence, or it have links on the other side. Theology is closely related to culture. Religion is seen as an integral part of culture, both of which are closely related. The religious norms prevailing in society usually become a repetitive habit, so that religious and cultural knowledge are integrated in their social life.

Some cases show the gap between culture, religion and STEM. This case carries the urgency of applying religious and cultural sciences to be applied in science learning, especially STEM education. The application of STEM by using religious and ethnics learning resources is expected to be a learning that can increase knowledge in the context of science that maintains culture and religion. Theology has an important part in shaping the STEM identity which both aspects reinforce one another. STEM identity needs to be developed based on the difference between students' religious beliefs and their learning concepts in class. The incorporation of religious and cultural knowledge into STEM learning (RE-STEM) seems to be interesting to implement in science education today.

\section{ACKNOWLEDGEMENTS}

Thank you to the Ministry of Education and Culture of Indonesian for providing the budget through the Thesis Magister Research scheme year 2020 with Research Agreement Contract Letter No. 71.23.3/UN37/PPK. 3.1/2020.

\section{REFERENCES}

[1] A. Anil, "Education in the 21st Century: The Dynamics of Change," The Research Journal of Social Science, vol. 10, no. 3, pp. 128-133, 2019.

[2] C. Tican and S. Deniz, "Pre-service Teachers' Opinions about the Use of 21st Century Learner and 21st Century Teacher Skills," European Journal of Educational Research, vol. 8, no. 1, pp. 181-197, 2018.

[3] I. Yuliana, "Ethnoscience Based Learning in Realizing Character Education for Elementary School Students (in Bahasa)," Elementary School Education Journal, vol. 1, no. 2a, pp. 2597-4122, 2017.

[4] K. V. Smith, J. Loughran, A. Berry, and C. Dimitrakopoulos, "Developing Scientific Literacy in a Primary School," International Journal of Science Education, vol. 34, no. 1, pp. 127-152, 2012.

[5] O. S. Abonyi, L. Achimugu, and N. M. I. Adibe, "Innovation in Science and Thecnology Education: A Case for Ethnoscience Based Science Classrooms," International Journal of Scientific Engineering Research, vol. 5, no. 1, pp. 52-56, 2014.

[6] C. A. Dewi, Y. Khery, and M. Erna, "An ethnoscience study in chemistry learning to develop scientific literacy," Interntional Journal of Science Education, vol. 8, no. 2, pp. 279-287, 2019.

[7] R. A. Fasasi, "Effects of ethnoscience instruction, school location, and parental educational status on learners' attitude towards science," International Journal of Science Education, vol. 39, no. 5, pp. 548-564, 2017. 
[8] S. Subali, B. Sarwi, and S. Rahmawati, "The Effect of Ethnoscience Based Contextual Learning toward Students' Learning Activity," Journal of Primary Education, vol. 8, no. 2, pp. 152-160, 2018.

[9] A. Alim, S Sarwi, and B. Subali, "Implementation of Ethnoscience-based Guided Inquiry Learning on The Scientific Literacy and The Character of Elementary School Students," Journal of Primary Education, vol. 9, no. 2, pp. 139-147, 2019.

[10] A. Ariningtyas, S. Wardani, and F.W. Mahatmanti, "The Effectiveness of Student Worksheets with Ethnoscience in Salt Hydrolysis Material to Improve Science Literacy of High School Students (in Bahasa)," Journal of Innovative Science Education, vol. 6, no. 2, pp. 890-896, 2017.

[11] K. Donohue, G.A., Buck, and V. Akerson, "Where's the science? Exploring a new science teacher educator's theoretical and practical understandings of scientific inquiry," International Journal of Research in Education and Science (IJRES), vol. 6, no. 1, pp. 1-13, 2020.

[12] Y. M. Yusof, A. Tajuddin, S. S. Abd Azis, and M. A. Othoman, "Determinant Factor of the 21st Century Teaching and Learning Skill among the College Community Entrepreneurship Lecturer in College Community Perak, Malaysia.," International Journal of Bssiness and Social Science, vol. 9, no. 6, pp. 87-91, 2018.

[13] J. McPhetres and M. Zuckerman, "Religiosity predicts negative attitudes towards science and lower levels of science literacy," PLOS ONE, vol. 13, no. 11, pp. 1-20, 2018.

[14] S. H. Jones, R. Catto, T. Kaden, and F. Elsdon-Baker, "That's how Muslims are required to view the world': Race, culture and belief in non-Muslims' descriptions of Islam and science," Sociological Review, vol. 67, no. 1, pp. 1-17, 2019.

[15] R. Kang and J. Peters, Dunhuang as a Model for EthnoSTEM Education. The Dunhuang Grottoes and Global Education, Part of the Spirituality, Religion, and Education book series (SPRE). Springer Link. pp. 135-160, 2019.

[16] S. L. Rodriguez, R. Friedensen, T Marron, and \& Bartlett, M, "Latina Undergraduate Students in STEM: The Role of Religious Beliefs and STEM Identity," Journal of College and Character, vol. 20, no. 1, pp. 25-46, 2019.

[17] C. P. Scheitle and E. H. Ecklund, "Perceptions of Religious Discrimination among U.S. Scientists," Journal for the Scientific Study of Religion, vol. 57, no. 1, pp 139-155, 2018.

[18] T. Kaden, S. Jones, R. Catto, and F. Elsdon-Baker, "Knowledge as Explanandum," Studies in Religion/Sciences Religieuses, vol. 47, no. 4, pp. 500-521, 2018.

[19] J. C. Jochman, A. Swendener, J. McQuillan, and L. Novack, "Are Biological Science Knowledge, Interests, and Science Identity Framed by Religious and Political Perspectives in the United States," The Sociological Quarterly, vol. 59, no. 4, pp. 584-602, 2018.

[20] D. K. Manson, "Science with a Soul," Studies in Religion/Sciences Religieuses, vol. 47, no. 2, pp. 246-262, 2017.

[21] A. Akbar, "Islam-science relation from the perspective of postrevolutionary Iranian religious intellectuals, British Journal of Middle Eastern Studies," British Journal of Middle Eastern Studies, vol. 46, no. 1, pp. 104-122, 2019.

[22] P. Schwadel, "Does Higher Education Cause Religious Decline? A Longitudinal Analysis of the Within- and Between-Person Effects of Higher Education on Religiosity," Sociological Quarterly, vol. 57, no. 4, pp. 759-786, 2016.

[23] C. Stanford et al., "Supporting sustained adoption of education innovations: The Designing for Sustained Adoption Assessment Instrument," International Journal of STEM Education, vol. 3, no. 1, p. 2010, 2016.

[24] T. L. O'Brien and S. Noy, "Cultural Authority in Comparative Context: A Multilevel Analysis of Trust in Science and Religion," Journal for the Scientific Study of Religion, vol. 57, no. 3, pp. 495-513, 2016.

[25] P. Black, "Christian beliefs and values in science and religious education: an essay to assist the work of teachers of both subjects," International Studies in Catholic Education, vol. 9, no. 2, pp. 206-222, 2017.

[26] D. H. Glass, "Explaining Away and the Cognitive Science of Religion," Theology and Science, vol. 14, no. 3, pp. 288-304, 2016.

[27] T. R. Kelley and J. G. Knowles, "A conceptual framework for integrated STEM education," International Journal of STEM Education, vol. 3, no. 1, 2016. [Online]. Available: https://doi.org/10.1186/s40594-016-0046-z

[28] E. H. Ecklund, C. P. Scheitle, and J. Peifer, "The Religiosity of Academic Scientists in the United Kingdom: Assessing the Role of Discipline and Department Status," Journal for the Scientific Study of Religion, vol. 57, no. 4, pp. 743-757, 2018.

[29] D. Fortus and L. Daphna, "Adolescents' goal orientations for science in single-gender Israeli religious schools," International Journal of Science Education, vol. 39, no. 1, pp. 86-103, 2017.

[30] J. L. Francis, J. Astley, and U. McKenna, "'Science disproves the biblical account of creation': exploring the predictors of perceived conflict between science and religion among 13- to 15-year-old students in the UK," British Journal of Religious Education, vol. 41, no. 2, pp. 188-201, 2019.

[31] T. Walker, "Science and religion in the classroom: A philosophical approach," International Studies in Catholic Education, vol. 13, no. 1, pp. 96-109, 2019.

[32] J. Pearce, A. Stones, M. J. Rreiss, and T. Mujtaba, "Science is purely about the truth so I don't think you could compare it to non-truth versus the truth.' Students' perception of religion and science, and the relationship(s) between them: religious education and for the need for epistemic literacy," British Journal of Religious Education, pp. 1-16, 2019. [Online]. Available: https://doi.org/10.1080/01416200.2019.1635434

[33] T. Harvie, "Our Intertwined Animality: Forgoing Ultimacy for Intimacy in Dialogue with Eschatology and Science," Studies in Religion/Sciences Religieuses, vol. 49, no. 1, pp. 73-85, 2019.

[34] J. Astley and L.J. Francis, "Promoting positive attitudes toward science and religion among sixth-form pupils: dealing with scientism and creationism," British Journal of Religious Education, vol. 32, no. 3, pp. 189-200, 2010. 
[35] B. Billingsley, R. Brock, K. S. Taber, and F. Riga, "How Students View the Boundaries Between Their Science and Religious Education Concerning the Origins of Life and the Universe," Science Education, vol. 100, no. 3, pp. 459-482, 2016.

[36] T. Peters, "Science and Religion: Ten Models of War, Truce, and Partnership," Theology and Science, vol. 16, no. 1, pp. 11-53, 2017.

[37] Y. Ikkatai, et al., "Parental egalitarian attitudes towards gender roles affect agreement on girls taking STEM fields at university in Japan," International Journal of Science Education, vol 41, no. 16, pp. 1-17, 2019.

[38] H. Rock, "A plea to end Platonist theology posing as the Science of Religion: religion as a cultural system reasserted," International Review of Sociology, vol. 27, no. 3, pp. 1-22, 2017.

[39] Z. B. Arslan, "Reading the Universe with Heart and Practicing Science as Religious Ethics: Reconciling Islam and Science in Contemporary Turkey," Social Epistemology, vol. 34, no. 3, pp. 1-16, 2019.

[40] T. Aechtner and M. S. Buchanan, "Science and religion perspectives at St. John's University of Tanzania (SJUT)," Journal of Contemporary Religion, vol. 33, no. 2, pp. 337-345, 2018.

[41] L. B. Wheeler, B. K. Mulvey, J. L. Maeng, M. R. Librea-Carden, and R. L. Bell, "Teaching the teacher: exploring STEM graduate students' nature of science conceptions in a teaching methods course," International Journal of Science Education, vol. 41, no. 14, pp. 1-21, 2019.

[42] J. W. Shane, I. C. Binns, L. Meadows, R. S. Hermann, and M. J. Benus, "Beyond Evolution: Addressing Broad Interactions between Science and Religion in Science Teacher Education," Journal of Science Teacher Education, vol. 27, no. 2, pp. 165-181, 2016.

[43] W. Proudfoot, "Religious experience and the cognitive science of religion," Religion, Brain \& Behavior, vol. 7, no. 1 , pp. 80-81, 2018.

[44] H. A. A. Hammad, "Role of Islamic Science Textbooks and Teaching Methods in Arab Schools and Universities and Ideological Extremism," Religious Education, vol. 109, no. 1, pp. 61-71, 2014.

[45] C. Drummond and B. Fischhoff, "Individuals with greater science literacy and education have more polarized beliefs on controversial science topics," Proceedings of the National Academy of Sciences, vol. 114, no. 36, pp. 9587-9592, 2017.

[46] A. Stones, J Pearce, M. J. Reiss, and M. Mujtaba," Students' Perceptions of Religion and Science, and How They Relate: the Effects of a Classroom Intervention," Religious Science: The official journal of the Religious Education Asociation, vol. 115, no. 3, pp. 349-363, 2020.

[47] N. Novis-Deutsch and C. Lifshitz, "When Bible and science interact: teachers' pedagogic and value challenges in teaching religious minority students in higher education settings," Teaching in Higher Education, vol. 21, no. 5, pp. 487-500, 2016.

[48] O.K. Okwara and F. T. Upu, "Effects of Ethno-Science Instructional Approach on Students' Achievement and Interest in Upper Basic Science and Technology in Benue State, Nigeria," International Journal of Scientific Research in Education, vol. 10, no. 1, p. 6, 2017.

[49] Utete, N. Christina, A. M. Ilukena, and S Gerson, "Exploring how modern sciences impede the development of indigenous knowledge (IK) [Ethno-science and Ethno-mathematics] in the Kavango East region: a case study," Journal for Studies in Humanities and Social Sciences, vol. 6, no. 2, pp 68-88, 2017.

[50] M. Livingston, "Quga x: An Ethnoscience Analysis of Ancient Unangax̂," Arctic Anthropology, vol. 53, no. 2, pp. 81-92, 2016.

[51] D. E. S. I. A. U. Asbanu and Babys, "The Development of Sound Wave Audacity Base Learning Media Using Ethnoscience Approach of Amanuban Tribe to Improve Physics Teacher Candidates? Science Process Skill," International Journal of Science and Research (IJSR), vol. 6, no. 11, pp. 324-329, 2017.

[52] W. Sumarni, "The influence of ethnoscience-based learning on chemistry to the chemistry's literacy rate of the prospective teachers," Unnes Science Education Journal, vol. 7, no. 2, pp. 119-233, 2018.

[53] Sudarmin, R. Febu, M. Nuswowati, and W. Sumarni, "Development of Ethnoscience Approach in The Module Theme Substance Additives to Improve the Cognitive Learning Outcome and Student's entrepreneurship," Journal of Physics: Conf. Series, vol. 824, no. 1, pp. 012024, 2017.

[54] M. C. Simi, E. R. Aneena, S. T. Panjikkaran, C. L. Sharon, and K. B. Sheela, "Standardisation and quality evaluation of Queensland arrowroot (Canna edulis L.) Based custard powder," Journal of Tropical Agriculture, vol. 54, no. 1, pp. 35-40, 2016.

[55] F. A. Adesoji, N. A. Omilani, and O. A. Francis, "Teacher Variables and School Location as Predictors of Chemistry Teachers' Awareness of Ethno Science Practices," Journal of Education, Society and Behavioral Science, vol. 31, no. 1, pp. 1-17, 2019.

[56] Ø. L. Johannessen and G. Skeie, "The relationship between religious education and intercultural education," Intercultural Education, vol. 30, no. 3, pp. 260-274, 2018.

[57] V. Wong, J. Dillon, and H. King, "STEM in England: meanings and motivations in the policy arena," International Journal of Science Education, vol. 38, no. 15, pp. 2346-2366, 2016.

[58] V. Vallerand, "Teaching about Religion in a Democratic Society: An Analysis of the Quebec Ethics and Religious Culture Program," Religion \& Education, vol. 45, no. 3, pp. 1-17, 2019.

[59] T. D. Holmlund, K. Lesseig, and D. Slavit, "Making sense of "STEM education" in K-12 contexts," International Journal of STEM Education, vol. 5, no. 1, pp. 1-18, 2018.

[60] D. L. Carlisle and G. C. Weaver, "STEM education centers: catalyzing the improvement of undergraduate STEM education," International Journal of STEM Education, vol. 5, no. 47, pp. 1-21, 2018.

[61] D. Bell, "The reality of STEM education, design and technology teachers' perceptions: a phenomenographic study," International Journal of Technology and Design Education, vol. 26, no. 1, pp. 61-79, 2016. 
[62] K. C. Margot and T. Kettler, "Teachers' perception of STEM integration and education: a systematic literature review," International Journal of STEM Education, vol. 6, no. 1, 2019.

[63] D. J. Shernoff, S. Sinha, D. M. Bressler, and L. Ginsburg, "Assessing teacher education and professional development needs for the implementation of integrated approaches to STEM education," International Journal of STEM Education, vol. 4, no. 13, pp. 1-16, 2017.

[64] E. A. Dare, E. A. Ring-Whalen, and G. H. Roehrig, "Creating a continuum of STEM models: Exploring how K-12 science teachers conceptualize STEM education," International Journal of Science Education, vol. 41, no. 12, pp. 1701-1720, 2019.

[65] C. Craig, R. Verma, D. Stokes, P. Evans, and B. Abrol, "The influence of parents on undergraduate and graduate students' entering the STEM disciplines and STEM careers," International Journal of Science Education, vol. 40, no. 6, pp. 621-643, 2018.

[66] K. Piatek-Jimenez, J. Cribbs, and N. Gill, "College students' perceptions of gender stereotypes: making connections to the underrepresentation of women in STEM fields," International Journal of Science Education, vol. 40, no. 12, pp. 1-23, 2018.

[67] A. Sahin, A. Ekmekci, and H. C. Waxman, "The relationships among high school STEM learning experiences, expectations, and mathematics and science efficacy and the likelihood of majoring in STEM in college," International Journal of Science Education, vol. 39, no. 11, pp. 1549-1572, 2017.

[68] H. Tzu-Ling, "Gender differences in high-school learning experiences, motivation, self-efficacy, and career aspirations among Taiwanese STEM college students," International Journal of Science Education, vol. 41, no. 13, pp. 1870-1884, 2019.

[69] S. Han, "Korean students' attitudes toward STEM project-based learning and major selection," Educational Sciences: Theory \& Practice, vol. 17, no. 2, pp. 529-548, 2017.

[70] A. Struyf, H. De Loof, J. Boeve-de Pauw, and P. Van Petegem, "Students' engagement in different STEM learning environments: integrated STEM education as promising practice," International Journal of Science Education, vol. 41, no. 10, pp. 1387-1407, 2019.

[71] S. Akaygun and F. Aslan-Tutak, "STEM images revealing stem conceptions of pre-service chemistry and mathematics teachers," International Journal of Education in Mathematics, Science and Technology, vol. 4, no. 1, pp. 56-71, 2016.

[72] E. Baran, S. Canbazoglu Bilici, C. Mesutoglu, and C. Ocak, "Moving STEM beyond schools: Students' perceptions about an out-of-school STEM education program," International Journal of Education in Mathematics, Science and Technology, vol. 4, no. 1, pp. 9-19, 2018.

[73] J. Vennix, P. den Brok, and R. Taconis, "Do outreach activities in secondary STEM education motivate students and improve their attitudes towards STEM?" International Journal of Science Education, vol. 40, no. 11, pp. 1263-1283, 2019.

[74] N. Khoeroningtyas, A. Permanasari, and I. Hamidah, "STEM Learning in Material of Temperatureand Its Change to Improve Scientific Literacy of Junior High School Students," Jurnal Pendidikan IPA Indonesia, vol. 5, no. 1, pp. 94-100, 2016.

[75] M. E. Barnes, J. M., Truong, and S. E. Brownell, "Experiences of Judeo-Christian Students in Undergraduate Biology," CBE_Life Sciences Education, vol. 16, no. 1, pp. 1-16, 2017. 